\title{
Nitrogen gas flushing can be bactericidal: the temperature-dependent destiny of Bacillus weihenstephanensis KBAB4 under a pure $\mathrm{N}_{2}$ atmosphere
}

\section{Patricia Munsch-Alatossava * and Tapani Alatossava}

Division of Food Technology, Department of Food and Environmental Sciences, University of Helsinki, Helsinki, Finland

Edited by:

Charles W. Knapp, University

of Strathclyde, UK

\section{Reviewed by:}

Dinesh Sriramulu, Shres

Consultancy, India

Seánín Marie McCluskey,

GT Biologics, UK

\section{*Correspondence:}

Patricia Munsch-Alatossava, Division of Food Technology, Department of Food and Environmental Sciences, University of Helsinki, PO Box 66, Fl-00014 Helsinki, Finland e-mail: patricia.munsch@helsinki.fi
Gram-negative Pseudomonas and Gram-positive Bacillus are the most common spoilage bacteria in raw and pasteurized milk, respectively. In previous studies, nitrogen $\left(\mathrm{N}_{2}\right)$ gas flushing treatments of raw and pasteurized milk at cold chain-temperatures inhibited bacterial spoilage and highlighted different susceptibilities to the $\mathrm{N}_{2}$ treatment with the exclusion of certain bacterial types. Here, we investigated the effects of pure $\mathrm{N}_{2}$ gas flushing on representative strains of these genera grown in mono- or co-cultures at 15 and $25^{\circ} \mathrm{C}$. Bacillus weihenstephanensis, a frequent inhabitant of fluid dairy products, is represented by the genome-sequenced KBAB4 strain. Among Pseudomonas, P. tolaasii LMG $2342^{\top}$ and strain $\mathrm{C1}$, a raw milk psychrotroph, were selected. The $\mathrm{N}_{2}$ gas flushing treatment revealed: (1) temperature-dependent responses; (2) inhibition of the growth of both pseudomonads; (3) emergence of small colony variants (SCVs) for $B$. weihenstephanensis strain $\mathrm{KBAB} 4$ at $15^{\circ} \mathrm{C}$ induced by the $\mathrm{N}_{2}$ treatment or when grown in co-culture with Pseudomonas strains; (4) $\mathrm{N}_{2}$ gas flushing modulates (suppressed or stimulated) bacterial antagonistic reactions in co-cultures; (5) most importantly, scanning electron microscopy (SEM) and transmission electron microscopy (TEM) analyses revealed that at $25^{\circ} \mathrm{C}$ the majority of the KBAB4 cells were killed by pure $\mathrm{N}_{2}$ gas flushing. This observation constitutes the first evidence that $\mathrm{N}_{2}$ gas flushing has bactericidal effects.

\section{Keywords: nitrogen gas, bactericidal, Bacillus, Pseudomonas, small colony variants}

\section{INTRODUCTION}

The challenges presently faced by food production systems require the urgent development of additional steps to alleviate food-borne pathogens and to tackle food spoilage. In developed and developing countries, as much as $30-40 \%$ of the food produced is lost to waste (Godfray et al., 2010). In developing regions, the waste of milk, for example, is relatively high during post-harvest handling and storing (Gustavsson et al., 2011). In developed countries, numerous studies point to the vulnerability of the cold chain for raw or pasteurized milk. Milk is colonized by numerous "psychrotrophic" or "psychrotolerant" bacterial types which can easily grow at refrigeration temperatures and induce spoilage (Cousin, 1982; Hayes and Boor, 2001). Most psychrotrophic bacteria found in raw milk, many of which are Gram negative bacteria, are generally considered as benign; their spoilage features arise from various heat-stable exoenzymes that degrade the different milk components. In addition, the trends in antibiotic resistance levels observed in psychrotrophic bacterial populations over time during the cold storage of raw milk suggest that bacterial growth should be prevented by supplementary means (Munsch-Alatossava and Alatossava, 2007; Munsch-Alatossava et al., 2012a,b). Many studies have examined complementary methods to cold storage to control bacterial growth in highly perishable fluid milk products (Murray et al., 1983;
Ruas-Madieodo et al., 1996; Dechemi et al., 2005; Rajagopal et al., 2005).

We investigated at the laboratory scale, the possibility of flushing raw milk with pure $\mathrm{N}_{2}$ gas, applied in an "open system." Treatments at 6,7 , and $12^{\circ} \mathrm{C}$ hindered bacterial growth and affected the spoilage potential (Munsch-Alatossava et al., 2010a; Munsch-Alatossava and Alatossava, 2011a). More strikingly, some bacterial types were particularly targeted: colonies that correspond to Bacillus cereus-type (cultured on Mannitol Egg Yolk Polymyxin B agar plates) proliferated in control conditions during the cold storage of milk; contrarily to flushed raw milk samples, for which B. cereus-type colonies, if initially present, were no longer found (Munsch-Alatossava et al., 2010a). Considering only bacteria that are able to grow on egg yolk agar, phospholipases-producers present in raw milk were "sooner or later" excluded from the agar plates under the flushing treatment (Munsch-Alatossava et al., 2010a,b). Among the bacterial types, retrieved from flushed milk on Mac- Conkey agar, lactose nonfermenters seemed to be particularly targeted compared to the controls (Munsch-Alatossava, Gursoy, Alatossava, unpublished data). Noteworthy, the most sensitive groups at the laboratory scale were also hindered by the treatments at the pilot plant scale, when $\mathrm{N}_{2}$ gas was extracted and concentrated from the surrounding atmosphere to treat raw milk (Munsch-Alatossava et al., 2011b). 
We recently explored the possibility of flushing pasteurized milk following the pasteurization step and observed that bacterial growth was inhibited up to 35 days at $6^{\circ} \mathrm{C}$, when the treatment was applied shortly after pasteurization; Bacillus weihenstephanensis was frequently isolated from controls or $\mathrm{N}_{2}$-flushed pasteurized milk (Munsch-Alatossava et al., 2013). Previous reports indicated that $B$. weihenstephanensis is commonly found in fluid milk (Huck et al., 2009; Ivy et al., 2012). B. weihenstephanensis was earlier distinguished from $B$. cereus by its ability to grow at 7 and not at $43^{\circ} \mathrm{C}$ (Lechner et al., 1998; Von Stetten et al., 1999) observed that $B$. weihenstephanensis was still able to grow at $38^{\circ} \mathrm{C}$. The species comprises most of the psychrotolerant strains of $B$. cereus. Based on phenotypic and genotypic features, the bacterium was ascribed to the phylogenetic group VI of $B$. cereus (Guinebretière et al., 2008). Recent reports point to potential health risks. The production of cereulide was observed at $8^{\circ} \mathrm{C}$ in two $B$. weihenstephanensis environmental strains (Thorsen et al., 2006). The B. weihenstephanensis KBAB4 strain, considered to be moderately psychrotolerant, was more virulent at low temperature $\left(15^{\circ} \mathrm{C}\right)$ compared to $30^{\circ} \mathrm{C}$ (Lapidus et al., 2008; Réjasse et al., 2012). A recent report proposed that because, some strains were able to grow at temperatures as low as $6^{\circ} \mathrm{C}$ and to produce toxin at $8^{\circ} \mathrm{C}, \mathrm{B}$. weihenstephanensis should be considered as potentially hazardous for refrigerated foods (Markland et al., 2013).

To clarify previous observations from the investigations of raw and pasteurized milk microbiota and to increase our knowledge of bacterial inhibition or exclusion under $\mathrm{N}_{2}$ treatments, representative Gram-positive and Gram-negative bacteria were studied in single or dual cultures, at two temperatures $\left(15\right.$ and $\left.25^{\circ} \mathrm{C}\right)$. The combinations were composed of the strain KBAB4 challenged with one of two pseudomonads: Pseudomonas tolaasii, a common mushroom pathogen (Rainey et al., 1991) that is occasionally found in milk (Wiedmann et al., 2000), and the Pseudomonas spp. raw milk psychrotrophic isolate $\mathrm{C} 1$. C1 represents the ideal spoilage candidate because it has protease, lipase, phospholipase activities; it is also haemolytic and has antibiotic multiresistance features (Munsch-Alatossava and Alatossava, 2006, 2007).

This study was designed to determine whether pure $\mathrm{N}_{2}$ flushing has deleterious effects on bacterial strains grown as single or dual cultures, and whether the temperature modulates the effects of the $\mathrm{N}_{2}$ flushing. We asked whether sporulation of $B$. weihenstephanensis was promoted by the treatments. We also asked what types of bacterial interactions are present in the co-cultures and whether $\mathrm{N}_{2}$ flushing modifies these interactions.

\section{MATERIALS AND METHODS \\ THE $\mathrm{N}_{2}$ GAS FLUSHING SYSTEM}

The gas flushing system has been fully described (MunschAlatossava et al., 2010a, 2013). Briefly, the $\mathrm{N}_{2}$ gas (99.999\% pure $\mathrm{N}_{2}$, AGA Ltd, Riihimäki, Finland) flow was adjusted to $120 \mathrm{ml} / \mathrm{mn}$ and entered the culture flasks through sterile filters $(0.22 \mu \mathrm{m})$. Together with the corresponding controls, the flushed flasks were continuously mixed at $220 \mathrm{rpm}$ and were partially immersed in a water bath (MGW Lauda M/S); the temperature inside the flasks was $25 \pm 0.1^{\circ} \mathrm{C}$ or $15 \pm 0.1^{\circ} \mathrm{C}(99.5 \%$ ethanol was used as a cooling agent).

\section{BACTERIAL STRAINS AND MICROBIOLOGICAL STUDIES}

B. weihenstephanensis strain KBAB4, P. tolaasii strain LMG $2342^{\mathrm{T}}$ and the psychrotrophic Pseudomonas sp. raw milk isolate $\mathrm{C} 1$ were grown on Brain Heart Infusion (BHI, Lab M, Heywood, UK) agar; the strains were appropriately stored and routinely subcultured. At the beginning of the experiment, $5 \mu \mathrm{l}$ of overnight bacterial monocultures (in BHI broth) were added to $100 \mathrm{ml}$ of BHI broth, according to the experimental conditions. The following abbreviations identify the experimental conditions: $\mathrm{KC}$ and $\mathrm{KN}$ correspond to B. weihenstephanensis KBAB4 grown in control and $\mathrm{N}_{2}$ - flushed cultures, respectively; C1C, 42C, C1N, and $42 \mathrm{~N}$ correspond to the pseudomonads $\mathrm{C} 1$ and $\mathrm{LMG} 2342^{\mathrm{T}}$ grown in control and flushed cultures, respectively. The dual cultures are described as follows: the viable cells from the control and flushed cultures of $\mathrm{KBAB} 4$, grown in co-culture with $\mathrm{C} 1$, correspond to $\mathrm{K}(\mathrm{C} 1) \mathrm{C}$ and to $\mathrm{K}(\mathrm{C} 1) \mathrm{N}$, respectively; the levels of $\mathrm{C} 1$ or 42 in co-culture with $\mathrm{KBAB} 4$ correspond to $\mathrm{C} 1(\mathrm{~K}) \mathrm{C}$ and $42(\mathrm{~K}) \mathrm{C}$, $\mathrm{C} 1(\mathrm{~K}) \mathrm{N}$ and $42(\mathrm{~K}) \mathrm{N}$ for the controls and flushed co-cultures, respectively.

Following inoculation, at the different sampling times, the $\mathrm{N}_{2}$ flow was briefly interrupted and $500 \mu \mathrm{l}$ of bacterial cultures was retrieved, serially diluted in saline solution $(0.85 \% \mathrm{NaCl})$, and cultured on BHI agar when KBAB4 was grown alone, or in coculture with LMG $2342^{\mathrm{T}}$ or C1. The viable cell counts for LMG $2342^{\mathrm{T}}$ and $\mathrm{C} 1$ were separately determined on Mac-Conkey agar (Difco, Becton Dickinson, USA). The bacterial counts were determined from triplicate platings after incubation at $30^{\circ} \mathrm{C}$ for $24 \mathrm{~h}$. Spore levels from cultures, that contained the strain KBAB4 in mono- or co-culture, were determined following a heat treatment of $500 \mu \mathrm{l}$ of culture samples at $80^{\circ} \mathrm{C}$ for $12 \mathrm{~min}$ and platings on $\mathrm{BHI}$ agar. The plates were incubated at $30^{\circ} \mathrm{C}$ for $24-48 \mathrm{~h}$.

\section{ELECTRON MICROSCOPY OF BACTERIAL CELLS}

The analyses were performed at the end of the flushing treatments for both control and flushed cultures of B. weihenstephanensis $\mathrm{KBAB} 4$ grown as a single culture, at 15 and $25^{\circ} \mathrm{C}$. For electron microscopy (EM) analysis, the cells were fixed with $2.5 \%$ glutaraldehyde (GA) by adding $110 \mu \mathrm{l}$ of a $25 \%$ GA stock solution [EM-grade, Electron Microscopy Sciences (EMS), Hatfield, $\mathrm{PA}, \mathrm{USA}$ ] to a $1 \mathrm{ml}$ bacterial culture in a $1.5 \mathrm{ml}$ Eppendorf tube. The samples were mixed thoroughly, and kept for $2 \mathrm{~h}$ at room temperature (RT) to complete the fixation. The GAfixed cells were pelleted by centrifugation at $5900 \times \mathrm{g}$ for $5 \mathrm{~min}$ (Eppendorf 5415D), after which the supernatant was removed, and the pellet of the GA-fixed cells was suspended in $1 \mathrm{ml} 0.1 \mathrm{M}$ Na-phosphate buffer ( $\mathrm{pH}$ 6.8) by thorough vortex-mixing. The samples of GA-fixed bacterial cell suspensions were stored at $4^{\circ} \mathrm{C}$ for scanning electron microscopy (SEM) and transmission electron microscopy (TEM) specimen preparations and analyses at the Electron Microscopy Unit (Institute of Biotechnology, University of Helsinki). Standard specimen preparation techniques for SEM and TEM analysis were used. The SEM specimens of the GA-fixed bacterial cell suspensions were dehydrated with a graded series of ethanol (30, 50, 70, 96, and 100\%), dried with hexamethyldisilazane, mounted into aluminum stubs and coated with platinum. The specimens were examined in a Quanta FEG250 (FEI Europe, Eindhoven, Netherlands) scanning electron 
microscope. The TEM specimens of the GA-fixed bacterial cell suspensions were post-fixed with $1 \%$ osmium tetroxide (EMS) for $1 \mathrm{~h}$ at RT, followed by dehydration with a graded series of ethanol (30, 50, 70, 96, and 100\%) and acetone, and finally embedded gradually in hard Epon resin (TAAB Embedding). Each Epon-embedded specimen was sectioned; sections containing bacterial cell material were further picked up on the Pioloformcoated one hole-type grid and were post-stained with aqueous uranyl acetate and lead citrate. The specimens were examined in a JEM-1400 (Jeol Ltd., Tokyo, Japan) transmission electron microscope.

\section{RESULTS}

EFFECT OF $\mathrm{N}_{2}$ FLUSHING ON THE GROWTH OF BACTERIAL MONO- AND CO-CULTURES AT $25^{\circ} \mathrm{C}$

The enumeration of viable cells from KBAB4 grown in monoculture revealed that, irrespective of the conditions, both the control (KC) and the treated (KN) cultures followed a similar growth trend during the first $24 \mathrm{~h}$, marking the end of the
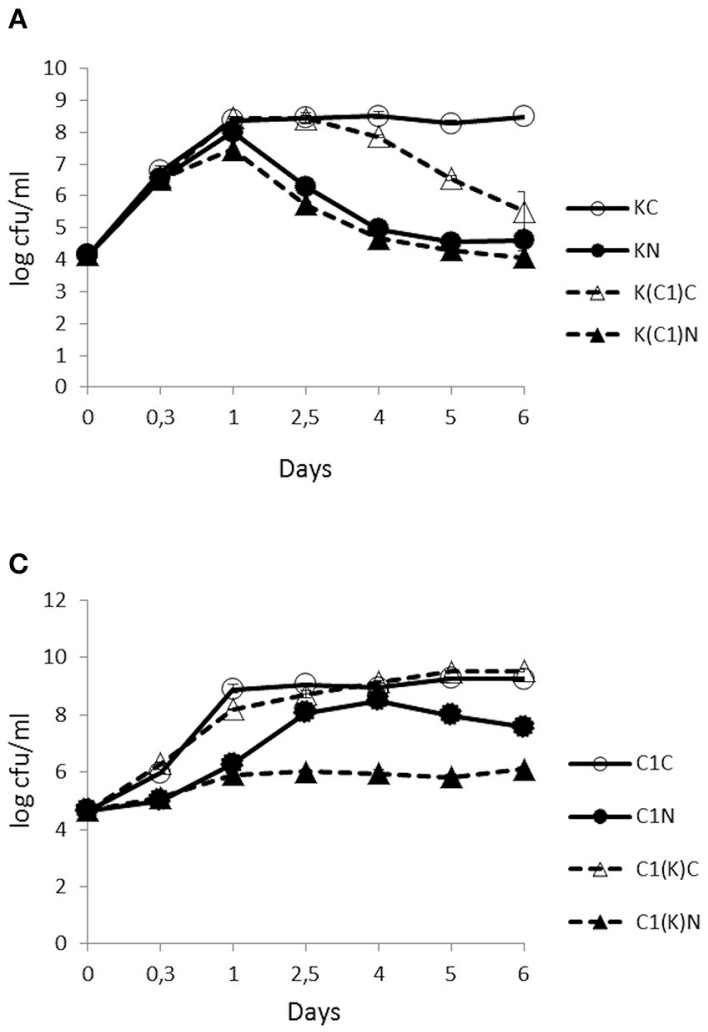

FIGURE 1 | Time-course analyses of the number ( $\mathrm{cfu} / \mathrm{ml}$ ) of $B$. weihenstephanensis KBAB4 cells (K) established as mono- or co-cultures in $\mathrm{BHI}$ broth at $25^{\circ} \mathrm{C}$ with (A) a Pseudomonas raw milk isolate C1 (C1) or (B) $P$ tolaasii LMG $2342^{\mathbf{T}}$ (42). Similarly, the number (cfu/ml) of (C) Pseudomonas strain C1 (C1) or (D) LMG $2342^{\top}$ (42) cells as mono- or co-cultures with Bacillus strain KBAB4 under continuous pure $\mathrm{N}_{2}$ gas flushing $(\mathrm{N})$ together with the control conditions (C). Error bars indicate standard deviations. (A,B) $\mathrm{KC}$, monoculture of $B$. weihenstephanensis KBAB4 as control; KN, monoculture of $B$. weihenstephanensis KBAB4 flushed with $\mathrm{N}_{2} ; \mathrm{K}(\mathrm{C} 1) \mathrm{C}, \mathrm{KBAB} 4$ grown in the presence of $\mathrm{C} 1$ as control; exponential growth phase. In the subsequent stationary phase, the control culminated at approximately $8.5 \log$-units during the remaining 5-6 days (Figures 1A,B). In contrast, under the $\mathrm{N}_{2}$ treatment, KBAB4 (KN) gradually decreased after $24 \mathrm{~h}$; the level of the surviving cells was reduced by four log-units (approximately 10,000-fold) compared to the control (KC), after 5 or 6 days of flushing at $25^{\circ} \mathrm{C}$ (Figures 1A,B).

\section{EM ANALYSES ON THE ULTRASTRUCTURE OF B. WEIHENSTEPHANENSIS CELLS AT $25^{\circ} \mathrm{C}$ REVEAL THE BACTERICIDAL EFFECT OF $\mathrm{N}_{2}$ GAS FLUSHING SEM}

At $25^{\circ} \mathrm{C}$, after 6 days of growth (Figure 1A), the untreated KBAB4 cells $(\mathrm{KC})$ from the control culture were rod-shaped, approximately 2-4 $\mu \mathrm{m}$ long, turgid, and displayed an intact smooth surface (Figure 2A). In contrast, at the end of the $\mathrm{N}_{2}$ flushing treatment (Figure 1A), cells that were flushed $(\mathrm{KN})$ were slightly shorter and thicker, with a more irregular and shrunken cell morphology. Most strikingly, many bubbles or vesicle-like round structures of varying sizes protruded from the cell surface; in
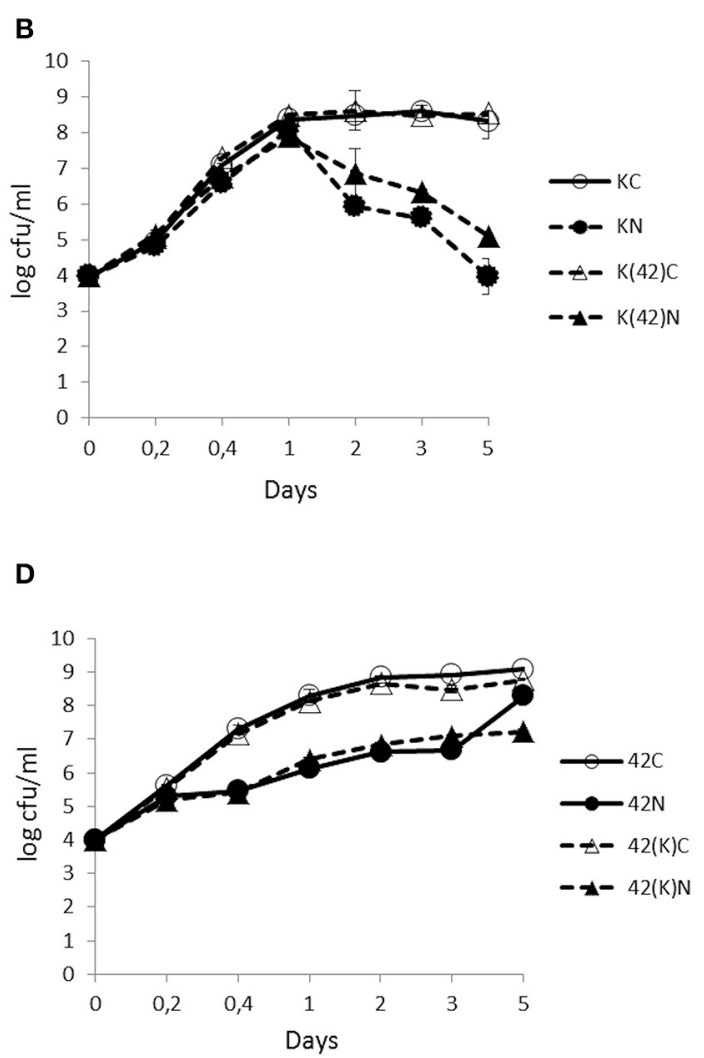

$\mathrm{K}(\mathrm{C} 1) \mathrm{N}, \mathrm{KBAB} 4$ grown in the presence of $\mathrm{C} 1$ flushed with $\mathrm{N}_{2} ; \mathrm{K}(42) \mathrm{C}$, KBAB4 grown in the presence of LMG $2342^{\top}$ as control; K(42)N, KBAB4 grown in the presence of LMG $2342^{\top}$ flushed with $\mathrm{N}_{2}$. (C) C1C, monoculture of the raw milk isolate $\mathrm{C} 1$ as control; $\mathrm{C} 1 \mathrm{~N}$, monoculture of the raw milk isolate $\mathrm{C} 1$ flushed with $\mathrm{N}_{2} ; \mathrm{C} 1(\mathrm{~K}) \mathrm{C}, \mathrm{C} 1$ grown in the presence of KBAB4 as control; $\mathrm{C} 1(\mathrm{~K}) \mathrm{N}, \mathrm{C} 1$ grown in the presence of KBAB4 flushed with $\mathrm{N}_{2}$. (D) $42 \mathrm{C}$, monoculture of LMG $2342^{\top}$ as control; $42 \mathrm{~N}$, monoculture of LMG $2342^{\top}$ flushed with $\mathrm{N}_{2} ; 42(\mathrm{~K}) \mathrm{C}$, LMG $2342^{\top}$ grown in the presence of KBAB4 as control; $42(\mathrm{~K}) \mathrm{N}, \mathrm{LMG} 2342^{\top}$ grown in the presence of KBAB4 flushed with $\mathrm{N}_{2}$. 

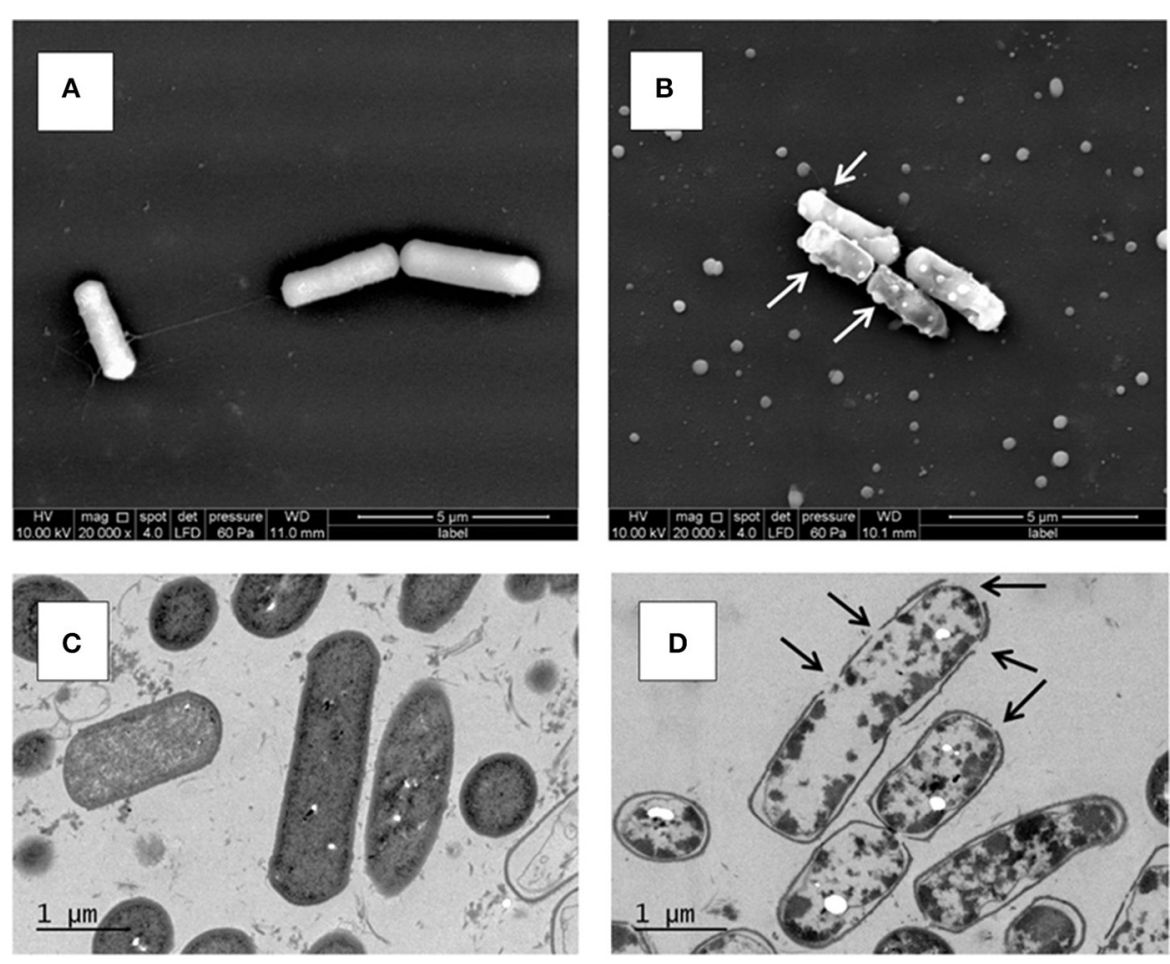

FIGURE 2 | Ultrastructure of $B$. weihenstephanensis KBAB4 cells grown at $25^{\circ} \mathbf{C}$ in $\mathbf{B H I}$ broth for $\mathbf{6}$ days. (A,B) SEM micrographs of cells from (A) the control culture ( $K C$ in Figure 1A) or (B) the $N_{2}$ flushed culture (KN in Figure 1A). White arrows indicate some of the cell wall-associated vesicle or bubble structures. (C,D) TEM micrographs of thin-sectioned cells from (C) the control culture (KC in Figure 1A) or (D) the $\mathrm{N}_{2}$ flushed culture ( $\mathrm{KN}$ in Figure 1A). Black arrows indicate hole-like disruptions in the cell wall. addition, free, small, round particles of varying sizes were found outside the cells (Figure 2B).

\section{TEM}

The unflushed control cells (KC) obtained from the end point of the experiment at $25^{\circ} \mathrm{C}$ after 6 days of growth (Figure 1A) revealed a regular ultrastructure in both longitudinal and transversal sections. The cell wall and cytoplasmic membrane were intact and integral for most cells, even though some dead cells were visible in the preparation (Figure 2C). In contrast, the cells of the $\mathrm{N}_{2}$ flushed culture $(\mathrm{KN})$ grown at $25^{\circ} \mathrm{C}$ for 6 days (Figure 1A), had lost their regular shape and were deformed. Moreover, the staining intensity of the cytoplasmic space was irregular and reduced compared to the control cells (Figure 2D). The majority of the $\mathrm{N}_{2}$ flushed cells were seriously damaged and shrunken; the cytoplasmic membrane was separated from the cell wall. The remnants of the cytoplasm were aggregated. Most significantly, the cell wall and possibly the cell membrane were locally disrupted in many places in a single cell. The presence of holes in the cell wall correlated with the appearance of the cells, which were more or less empty of their cytoplasmic content. Only a very limited number of cells retained their integrity (Figure 2D).

\section{INHIBITION OF THE GROWTH OF PSEUDOMONAS STRAINS UNDER $\mathbf{N}_{2}$ FLUSHING IN MONOCULTURE AT $25^{\circ} \mathrm{C}$}

Contrary to $\mathrm{KBAB} 4(\mathrm{~K})$, where $\mathrm{KN}$ grew as fast as $\mathrm{KC}$, the monocultures of the pseudomonads C1 (C1) and LMG $2342^{\mathrm{T}}$
(42) revealed that the $\mathrm{N}_{2}$ treatments $(\mathrm{C} 1 \mathrm{~N}$ and $42 \mathrm{~N}$ ) inhibited the growth of both strains; the exponential growth phases were delayed compared to the corresponding controls ( $\mathrm{C} 1 \mathrm{C}$ and $42 \mathrm{C}$ ) (Figures 1C,D). For example, $10^{8} \mathrm{cfu} / \mathrm{ml}$ was reached at approximately $2.5 \mathrm{~d}$ by $\mathrm{C} 1 \mathrm{~N}$, less than one day by C1C, almost $1 \mathrm{~d}$ by $42 \mathrm{C}$ and nearly $5 \mathrm{~d}$ by $42 \mathrm{~N}$ (Figures 1C,D).

\section{$\mathrm{N}_{2}$ FLUSHING MODIFIES BACTERIAL INTERACTIONS IN CO-CULTURE AT $25^{\circ} \mathrm{C}$}

The $\mathrm{N}_{2}$ flushing treatment did not impact the growth trend of KBAB4 co-cultured with $\mathrm{C} 1(\mathrm{~K}(\mathrm{C} 1) \mathrm{N}) ; \mathrm{KN}$ and $\mathrm{K}(\mathrm{C} 1) \mathrm{N}$ had similar bacterial counts on the same sampling days (Figure 1A). In contrast, for the control co-culture $(\mathrm{K}(\mathrm{C} 1) \mathrm{C})$, the number of KBAB4 cells gradually decreased after $2.5 \mathrm{~d}$ and was up to three log-units lower than the level of KBAB4 in the control of the monoculture (KC) after $6 \mathrm{~d}$ (Figure 1A). The growth of KBAB4 co-cultured with LMG $2342^{\mathrm{T}}$ remained mostly unaffected by the presence of LMG $2342^{\mathrm{T}}$ in either control $(\mathrm{K}(42) \mathrm{C})$ or $\mathrm{N}_{2}$-flushed $(\mathrm{K}(42) \mathrm{N})$ co-culture conditions (Figure 1B).

The strain $\mathrm{Cl}$ was more sensitive to the $\mathrm{N}_{2}$ flushing treatment when grown simultaneously with KBAB4 (Figure 1C). As a single culture, after $2.5 \mathrm{~d}$ growth, $\mathrm{C} 1$ increased up to eight $\log$ units under the $\mathrm{N}_{2}$ treatment $(\mathrm{C} 1 \mathrm{~N})$, whereas in coculture with $\mathrm{KBAB} 4$, the growth of $\mathrm{C} 1(\mathrm{C} 1(\mathrm{~K}) \mathrm{N})$ was repressed, as the bacterial levels remained stable at approximately six log-units for five consecutive days (Figure 1C). The presence of KBAB4 did not influence the growth of LMG $2342^{\mathrm{T}}$ in 
either control $\left(42(\mathrm{~K})\right.$ C) or $\mathrm{N}_{2}$-flushed $(42(\mathrm{~K}) \mathrm{N})$ cultures (Figure 1D).

\section{EFFECT OF N 2 FLUSHING ON THE GROWTH OF BACTERIAL MONO- AND CO-CULTURES AT $15^{\circ} \mathrm{C}$}

In the control conditions, $\mathrm{KBAB} 4$ in monoculture $(\mathrm{KC})$ achieved its exponential growth phase at approximately $2.2 \mathrm{~d}$ (Figure 3A); it then entered the stationary phase and the cell counts remained constant until the end of the experiment (day 11). Under the $\mathrm{N}_{2}$ gas flushing treatment, KBAB4 in monoculture $(\mathrm{KN})$ showed a peculiar cyclic growth trend, where total cell counts decreased or increased over time, without reaching the levels observed for the control on the corresponding sampling days (Figure 3A). At approximately 6 days of $\mathrm{N}_{2}$ flushing, the viable cell counts were the lowest and the culture was translucent. But, at the same sampling point, concomitant with the normal large colony type (a size similar to the colonies on the control plates of approximately $3-4 \mathrm{~mm}$ in diameter on BHI agar after $24 \mathrm{~h}$ incubation at $30^{\circ} \mathrm{C}$ ), small colony variants (SCVs) appeared (a colony size less than $1.5 \mathrm{~mm}$ to pin-point) and increased over the course of the experiments (Figure 3A, Table 1).

The appearance of SCVs was consistent with the $\mathrm{N}_{2}$ flushing treatment observed in all experiments at $15^{\circ} \mathrm{C}$ when $\mathrm{KBAB} 4$ was grown as a single culture, irrespective of the initial inoculum level; SCVs were initially lowest in the culture where KBAB4 was initially present at the lowest inoculum level (Figure 3A, Table 1). SCVs were not present in the control (KC) and appeared after 5-6 d of $\mathrm{N}_{2}$ flushing. The SCVs constantly grew over time by 2-2.5 log-units until the end of the experiment. After $6 \mathrm{~d}$, SCVs outnumbered the original large colony morphotype and approached control levels (KC) after $8 \mathrm{~d}$. Accordingly, at the end of the flushing treatments, the SCV phenotype predomined (Figure 3A).
A

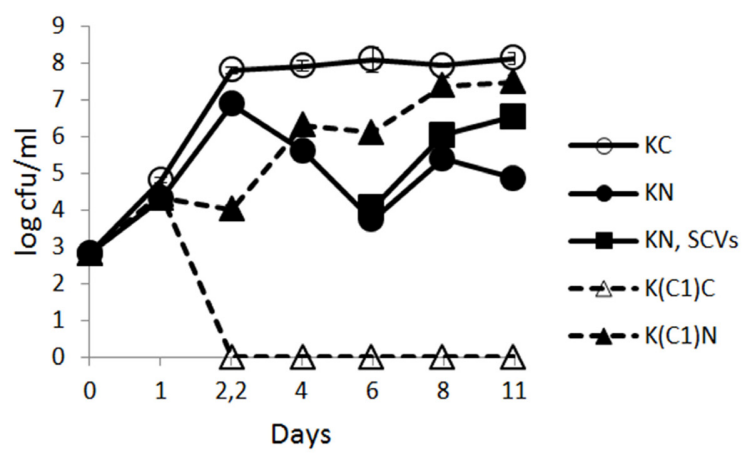

C

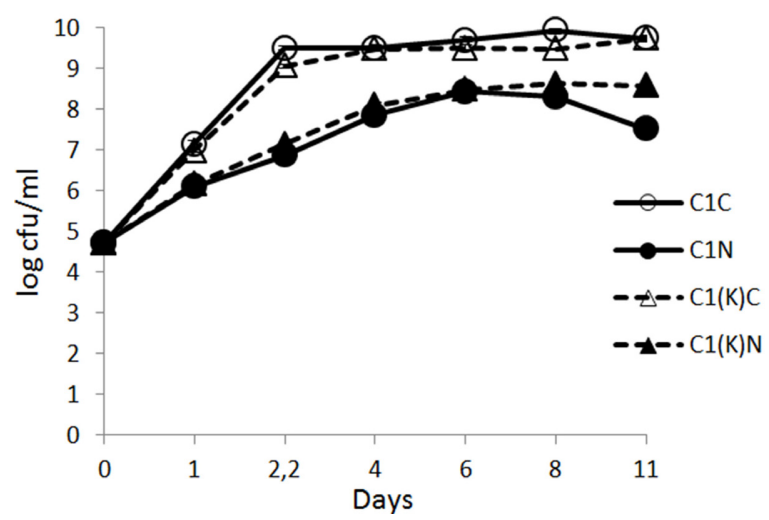

FIGURE 3 | Time-course analysis of the number (cfu/ml) of $B$. weihenstephanensis $\mathrm{KBAB} 4$ cells $(\mathrm{K})$ established as mono- or co-cultures in $\mathrm{BHI}$ broth at $15^{\circ} \mathrm{C}$ with (A) a Pseudomonas raw milk isolate C1 (C1) or (B) P. tolaasii LMG $2342^{\top}$ (42) together with the emergence of small colony variants (SCVs) in the KBAB4 strain monoculture. Similarly, the number (cfu/ml) of (C) Pseudomonas strain C1 (C1) or (D) LMG $2342^{\top}$ (42) cells as mono- or co-cultures with Bacillus strain KBAB4 under continuous pure $\mathrm{N}_{2}$ gas flushing (N) together with the control conditions (C). Error bars indicate standard deviations. (A,B) KC, monoculture of $B$. weihenstephanensis $\mathrm{KBAB} 4$ as control; $\mathrm{KN}$, monoculture of B. weihenstephanensis $\mathrm{KBAB} 4$ flushed with $\mathrm{N}_{2} ; \mathrm{KN}, \mathrm{SCV}$ s: small colony

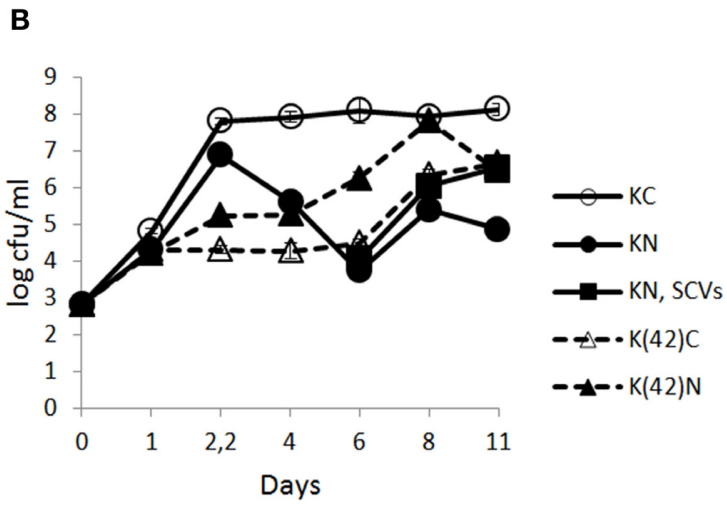

D

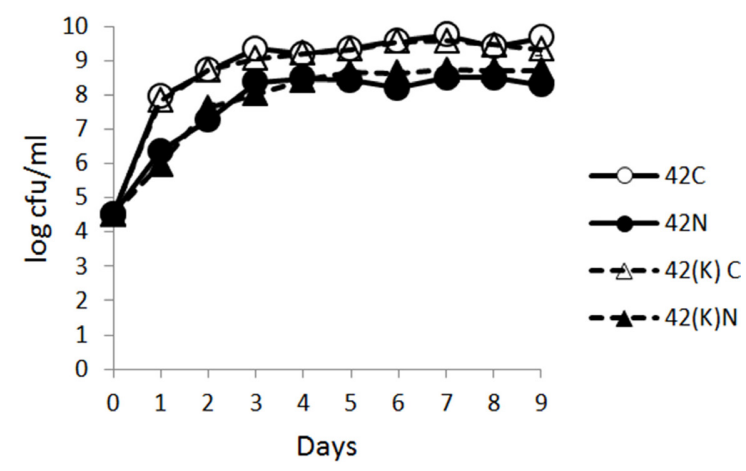

variants of $\mathrm{KBAB} 4 ; \mathrm{K}(\mathrm{C} 1) \mathrm{C}, \mathrm{KBAB} 4$ grown in the presence of $\mathrm{C} 1$ as control; $\mathrm{K}(\mathrm{C} 1) \mathrm{N}, \mathrm{KBAB} 4$ grown in the presence of $\mathrm{C} 1$ flushed with $\mathrm{N}_{2} ; \mathrm{K}(42) \mathrm{C}, \mathrm{KBAB} 4$ grown in the presence of LMG $2342^{\top}$ as control; K(42)N, KBAB4 grown in the presence of LMG $2342^{\top}$ flushed with $\mathrm{N}_{2}$. (C) C1C, monoculture of the raw milk isolate $\mathrm{C} 1$ as control; $\mathrm{C} 1 \mathrm{~N}$, monoculture of the raw milk isolate $\mathrm{C} 1$ flushed with $\mathrm{N}_{2} ; \mathrm{C} 1(\mathrm{~K}) \mathrm{C}, \mathrm{C} 1$ grown in the presence of KBAB4 as control; $\mathrm{C} 1(\mathrm{~K}) \mathrm{N}, \mathrm{C} 1$ grown in the presence of KBAB4 flushed with $\mathrm{N}_{2}$. (D) $42 \mathrm{C}$, monoculture of LMG $2342^{\top}$ as control; 42N, monoculture of LMG $2342^{\top}$ flushed with $\mathrm{N}_{2} ; 42(\mathrm{~K}) \mathrm{C}, \mathrm{LMG} 2342^{\top}$ grown in the presence of KBAB4 as control; 42(K)N, LMG $2342^{\top}$ grown in the presence of KBAB4 flushed with $\mathrm{N}_{2}$. 
Table 1 | Small colony variants as log cfu/ml that were enumerated from monocultures of $B$. weihenstephanensis KBAB4 (K) or from

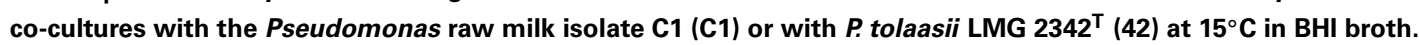

\begin{tabular}{|c|c|c|c|c|c|c|c|}
\hline \multirow{2}{*}{$\begin{array}{l}\text { EXPERIMENT A: } \\
\text { Day/Sample }\end{array}$} & \multicolumn{7}{|c|}{$\begin{array}{l}\text { INITIAL LEVELS: } \mathrm{C} 1=5.510^{4} \mathrm{cfu} / \mathrm{ml} ; \mathrm{K}=6500 \mathrm{cfu} / \mathrm{ml} ; 42=1.510^{4} \mathrm{cfu} / \mathrm{ml} \\
\text { INITIAL RATIOS: } \mathrm{C} 1 / \mathrm{K}=8.5 ; 42 / \mathrm{K}=2.3\end{array}$} \\
\hline & $\leq 5 \mathrm{~d}$ & $6 \mathrm{~d}$ & $7 \mathrm{~d}$ & $8 \mathrm{~d}$ & $9 \mathrm{~d}$ & $10 \mathrm{~d}$ & $12 d$ \\
\hline $\mathrm{KC}$ & 0 & 0 & 0 & 0 & 0 & 0 & 0 \\
\hline $\mathrm{KN}$ & 0 & $5.01 \pm 0.07$ & $6.17 \pm 0.06$ & $6.03 \pm 0.06$ & $7.08 \pm 0.19$ & $7.42 \pm 0.10$ & $7.23 \pm 0.07$ \\
\hline $\mathrm{K}(\mathrm{C} 1) \mathrm{C}$ & 0 & $6.35 \pm 0.18$ & $6.12 \pm 0.07$ & $6.08 \pm 0.09$ & $5.96 \pm 0.03$ & 0 & 0 \\
\hline $\mathrm{K}(\mathrm{C} 1) \mathrm{N}$ & 0 & $5.92 \pm 0.10$ & $6.85 \pm 0.10$ & $7.26 \pm 0.06$ & 0 & 0 & $5.99 \pm 0.08$ \\
\hline$K(42) C$ & 0 & $5.02 \pm 0.07$ & $5.84 \pm 0.13$ & $6.83 \pm 0.04$ & 0 & 0 & 0 \\
\hline $\mathrm{K}(42) \mathrm{N}$ & 0 & $6.52 \pm 0.09$ & $6.68 \pm 0.14$ & $7.05 \pm 0.12$ & $7.30 \pm 0.18$ & 0 & $6.79 \pm 0.18$ \\
\hline EXPERIMENT B: & \multicolumn{7}{|c|}{$\begin{array}{l}\text { INITIAL LEVELS: } \mathrm{C} 1=1.110^{5} \mathrm{cfu} / \mathrm{ml} ; \mathrm{K}=5750 \mathrm{cfu} / \mathrm{ml} ; 42=3.310^{4} \mathrm{cfu} / \mathrm{ml} \\
\text { INITIAL RATIOS: } \mathrm{C} 1 / \mathrm{K}=18.8 ; 42 / \mathrm{K}=5.7\end{array}$} \\
\hline Day/Sample & $\leq 4 \mathrm{~d}$ & $5 \mathrm{~d}$ & $6 \mathrm{~d}$ & $7 \mathrm{~d}$ & $8 \mathrm{~d}$ & \multicolumn{2}{|c|}{$9 \mathrm{~d}$} \\
\hline $\mathrm{KC}$ & 0 & 0 & 0 & 0 & 0 & \multicolumn{2}{|c|}{0} \\
\hline KN & 0 & $5.38 \pm 0.02$ & $6.43 \pm 0.04$ & $7.18 \pm 0.03$ & $7.27 \pm 0.06$ & \multicolumn{2}{|c|}{$7.39 \pm 0.04$} \\
\hline $\mathrm{K}(\mathrm{C} 1) \mathrm{C}$ & 0 & 0 & 0 & 0 & 0 & \multicolumn{2}{|c|}{0} \\
\hline $\mathrm{K}(\mathrm{C} 1) \mathrm{N}$ & 0 & $5.30 \pm 0.13$ & $6.86 \pm 0.04$ & $7.22 \pm 0.11$ & $7.06 \pm 0.38$ & \multicolumn{2}{|c|}{$6.95 \pm 0.02$} \\
\hline $\mathrm{K}(42) \mathrm{C}$ & 0 & $5.02 \pm 0.05$ & $5.91 \pm 0.06$ & $6.07 \pm 0.03$ & $6.84 \pm 0.02$ & \multicolumn{2}{|c|}{$6.82 \pm 0.03$} \\
\hline $\mathrm{K}(42) \mathrm{N}$ & 0 & $6.00 \pm 0.10$ & $7.07 \pm 0.18$ & $7.11 \pm 0.10$ & $6.89 \pm 0.15$ & \multicolumn{2}{|c|}{$6.62 \pm 0.12$} \\
\hline EXPERIMENT C: & \multicolumn{7}{|c|}{ INITIAL LEVELS: C1 = $5.410^{4} \mathrm{cfu} / \mathrm{ml} ; \mathrm{K}=685 \mathrm{cfu} / \mathrm{ml} ; 42=7.410^{4} \mathrm{cfu} / \mathrm{ml}$} \\
\hline \multicolumn{8}{|c|}{ INITIAL RATIOS: $\mathrm{C} 1 / \mathrm{K}=78 ; 42 / \mathrm{K}=108$} \\
\hline Day/Sample & $\leq 4 \mathrm{~d}$ & & $6 \mathrm{~d}$ & & $8 \mathrm{~d}$ & \multicolumn{2}{|c|}{$11 \mathrm{~d}$} \\
\hline KC & 0 & & 0 & & 0 & \multicolumn{2}{|c|}{0} \\
\hline $\mathrm{KN}$ & 0 & & $4.03 \pm 0.47$ & & $6.05 \pm 0.19$ & \multicolumn{2}{|c|}{$6.54 \pm 0.03$} \\
\hline $\mathrm{K}(\mathrm{C} 1) \mathrm{C}$ & 0 & & 0 & & 0 & \multicolumn{2}{|c|}{0} \\
\hline $\mathrm{K}(\mathrm{C} 1) \mathrm{N}$ & 0 & & 0 & & 0 & \multicolumn{2}{|c|}{0} \\
\hline $\mathrm{K}(42) \mathrm{C}$ & 0 & & $4.97 \pm 0.02$ & & 0 & \multicolumn{2}{|c|}{0} \\
\hline $\mathrm{K}(42) \mathrm{N}$ & 0 & & $6.81 \pm 0.10$ & & 0 & \multicolumn{2}{|c|}{0} \\
\hline
\end{tabular}

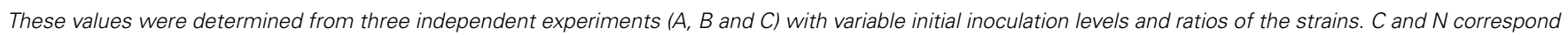
to the control and $\mathrm{N}_{2}$-flushed cultures, respectively.

\section{SEM ANALYSIS OF B. WEIHENSTEPHANENSIS KBAB4 CELL MORPHOLOGY REVEALED CHANGES IN CELL ORGANIZATION AT THE END OF $\mathrm{N}_{\mathbf{2}}$ GAS FLUSHING AT $15^{\circ} \mathrm{C}$}

KBAB4 cells of the control monoculture (KC) grown for $11 \mathrm{~d}$ at $15^{\circ} \mathrm{C}$ (Figure 3A) were of regular size and shape and were mostly organized as separate cells, but sometimes also as pairs where two cells were attached end-to-end (Figure 4A). In contrast, KBAB4 cells of the $\mathrm{N}_{2}$-flushed monoculture $(\mathrm{KN})$ grown for $11 \mathrm{~d}$ at $15^{\circ} \mathrm{C}$ (Figure 3A) were smaller, both in length and in width, but most significantly, these cells were primarily grouped in chains with very few free single cells (Figure 4B). As shown at a higher magnification, KBAB4 cells were attached to each other at their polar ends (Figures 4C,D).

\section{$\mathrm{N}_{2}$ GAS FLUSHING INHIBITS ALSO THE GROWTH OF PSEUDOMONAS AT $15^{\circ} \mathrm{C}$}

At $15^{\circ} \mathrm{C}$, the growth of Pseudomonas strain $\mathrm{C} 1$ in monoculture was inhibited by the $\mathrm{N}_{2}$ flushing treatment. $\mathrm{C} 1 \mathrm{C}$ and $\mathrm{C} 1 \mathrm{~N}$ reached $10^{8} \mathrm{cfu} / \mathrm{ml}$ after about $1.5 \mathrm{~d}$ and $4 \mathrm{~d}$, respectively (Figure 3C). Similarly, inhibitory effects were recorded for $P$. tolaasii LMG $2342^{\mathrm{T}}$ as a single culture under the $\mathrm{N}_{2}$ treatment; $42 \mathrm{C}$ and $42 \mathrm{~N}$ reached $10^{8} \mathrm{cfu} / \mathrm{ml}$ at $1 \mathrm{~d}$ and $2.2 \mathrm{~d}$, respectively (Figure 3D).

\section{$\mathrm{N}_{2}$ GAS FLUSHING MODIFIES BACTERIAL INTERACTIONS IN CO-CULTURE AT $15^{\circ} \mathrm{C}$}

At $15^{\circ} \mathrm{C}$, in the controls, $\mathrm{KBAB} 4(\mathrm{~K}(\mathrm{C} 1) \mathrm{C})$ was no longer detected at different time points, when it was co-cultured with $\mathrm{C} 1$. After $2.2 \mathrm{~d}$, it was completely eliminated in one co-culture with $\mathrm{C} 1$ (Figure 3A); the corresponding disappearance time points were $4 \mathrm{~d}$ and $12 \mathrm{~d}$ in the two other experiments (data not shown). Under the $\mathrm{N}_{2}$ flushing treatment, the growth of KBAB4 $(\mathrm{K}(\mathrm{C} 1) \mathrm{N})$ first followed $\mathrm{KN}$ but then entered a cyclic trend after $1 \mathrm{~d}$, which was asynchronous compared to $\mathrm{KN}$ (Figure 3A). After 4 days, the growth of $\mathrm{K}(\mathrm{C} 1) \mathrm{N}$ proceeded by stages and supplanted $\mathrm{KN}$.

In the control co-culture of KBAB4 and LMG $2342^{\mathrm{T}}$, the growth of KBAB4 was strongly inhibited after 1 day, while $\mathrm{K}(42) \mathrm{C}$ did not achieve the levels of the control monoculture $\mathrm{KC}$ (Figure 3B). Surprisingly, under $\mathrm{N}_{2}$ treatment, the inhibitory effect of LMG $2342^{\mathrm{T}}$ on KBAB4 was reduced, because the levels of $\mathrm{K}(42) \mathrm{N}$ were greater than $\mathrm{K}(42) \mathrm{C}$ (Figure 3B).

The emergence of SCVs was not restricted to $\mathrm{N}_{2}$-flushed monocultures of KBAB4 (Figure 3A, Table 1), but was also observed when $\mathrm{KBAB} 4$ was grown in co-culture with either $\mathrm{C} 1$ or LMG $2342^{\mathrm{T}}$ (Table 1). For several conditions, the rate of increase of SCVs in co-cultures exceeded that observed in monocultures, 

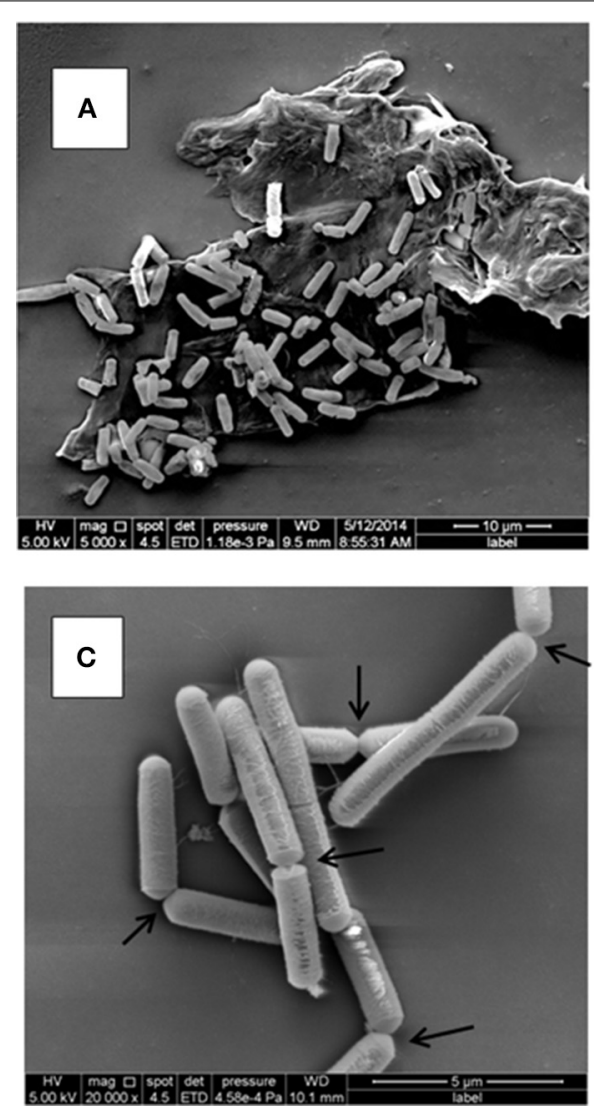

FIGURE 4 | Ultrastructure of $B$. weihenstephanensis KBAB4 cells grown at $15^{\circ} \mathrm{C}$ in $\mathrm{BHI}$ broth for 11 days. SEM micrographs of cells from (A) the control culture (KC in Figure $\mathbf{3 A}$ ) or (B-D) the $\mathrm{N}_{2}$-flushed
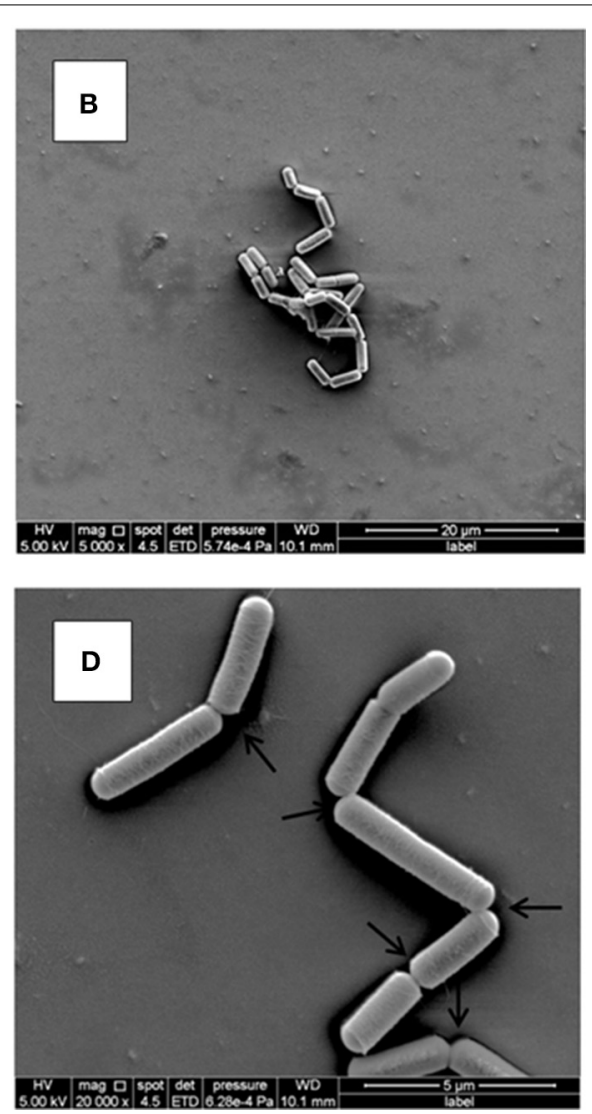

culture ( $\mathrm{KN}$ in Figure 3A). Arrows show some of the connections between the cells, organized as chains, indicating impaired cell separation. for which a more progressive trend was recorded. SCVs were only recorded transiently from days 6 to 9 for the $\mathrm{K}(\mathrm{C} 1) \mathrm{C}$ cells while $\mathrm{KBAB} 4$ decayed in the co-culture after 10 days (Experiment $\mathrm{A}$ in Table 1). No SCVs were recorded for the two other conditions when $\mathrm{KBAB} 4$ was eliminated from the co-culture with $\mathrm{C} 1$, after $2.2 \mathrm{~d}$ and $4 \mathrm{~d}$. SCVs were encountered for $\mathrm{K}(\mathrm{C} 1) \mathrm{N}$ in both conditions where the initial levels of KBAB4 were the highest, when the ratios of initial bacterial levels $\mathrm{C} 1 / \mathrm{K}$ were 8.5 and 18.8 (Experiments A and B in Table 1), respectively, but not in the condition where KBAB4 was the minor component (when the ratio $\mathrm{C} 1 / \mathrm{K}$ was 78 , Experiment $\mathrm{C}$ in Table $\mathbf{1}$ ).

For the co-cultures KBAB4/LMG $2342^{\mathrm{T}}$, both controls and the $\mathrm{N}_{2}$-flushed cultures had transient SCVs (at sampling day 6, Experiment $\mathrm{C}$ in Table 1) or for several consecutive days (Experiments A and B in Table 1). As shown in Table 1, during the first three days of the emergence of SCVs, the levels of SCVs in $\mathrm{N}_{2}$-flushed cultures $(\mathrm{K}(42) \mathrm{N})$ exceeded the levels of the corresponding controls $(\mathrm{K}(42) \mathrm{C})$. However, when $\mathrm{KBAB} 4$ was the minor component of the co-culture (the initial ratio $42 / \mathrm{K}$ was 108, Experiment C in Table 1), SCVs were absent from the control and were ephemeral in the treated culture. In contrast, the two other conditions had initial $42 / \mathrm{K}$ ratios of 2.3 and 5.7 (Experiments A and B in Table 1) and SCVs were more persistent, in either control or $\mathrm{N}_{2}$-flushed cultures.

\section{$\mathrm{N}_{2}$ GAS FLUSHING DOES NOT PROMOTE SPORULATION OF KBAB4 IN MONO- OR IN CO-CULTURES}

The enumeration of viable colonies after heat-treatment of the different cultures revealed that at $25^{\circ} \mathrm{C}$, under the $\mathrm{N}_{2}$ gas flushing treatment, KBAB4 was unable to sporulate in either mono- or cocultures (Table 2).

In the corresponding controls, the presence of spores was detected in monocultures of KBAB4 or when KBAB4 was associated with either C1 or LMG $2342^{\mathrm{T}}$ in all three experiments (Table 2). At $15^{\circ} \mathrm{C}$, no spores were detected in the controls and flushed cultures at the intermediate or final stages of the experiments, irrespective of the types of mono- or co-cultures of KBAB4.

\section{DISCUSSION}

All previous studies, that investigated the possibility of treating raw or pasteurized milk with pure $\mathrm{N}_{2}$ gas, examined the impact of the treatments on some bacterial types retrieved on certain agar types (Murray et al., 1983; Dechemi et al., 2005; MunschAlatossava et al., 2010a,b, 2013). Scarce but repeated observations allowed for an incomplete identification of the targeted bacteria among Gram- $(+)$ or Gram-(-) representatives, and prompted the present study to investigate whether at the cellular level, the treatment would have deleterious effect on certain bacterial types. 
Table 2 | Spore levels as log cfu/mla on BHI agar for $B$. weihenstephanensis KBAB4 $(\mathrm{K})$ grown in mono- or in co-cultures with the Pseudomonas raw milk isolate $\mathrm{C} 1$ or with $P$. tolaasii LMG $2342^{\top}(42)$ at $25^{\circ} \mathrm{C}$ in BHI broth.

\begin{tabular}{|c|c|c|c|c|c|c|c|c|c|}
\hline \multirow{2}{*}{$\begin{array}{l}\text { Experiment } \\
\text { Sample/Day }\end{array}$} & \multicolumn{3}{|c|}{ E.1 } & \multicolumn{3}{|c|}{ E.2 } & \multicolumn{3}{|c|}{ E.3 } \\
\hline & 0 & 3 & 5 & 0 & 1.5 & 5 & 0 & 2.5 & 6 \\
\hline $\mathrm{KC}$ & 0 & 0 & 3.9 & 0 & 0 & 3.2 & 0 & 2.3 & 2.7 \\
\hline $\mathrm{KN}$ & 0 & 0 & 0 & 0 & 0 & 0 & 0 & 0 & 0 \\
\hline $\mathrm{K}(\mathrm{C} 1) \mathrm{C}$ & & $N D^{b}$ & & 0 & 2.7 & 3.3 & 0 & 2.0 & 3.0 \\
\hline $\mathrm{K}(\mathrm{C} 1) \mathrm{N}$ & & $N D^{b}$ & & 0 & 0 & 0 & 0 & 0 & 0 \\
\hline $\mathrm{K}(42) \mathrm{C}$ & 0 & 3.9 & 4.6 & 0 & 3.7 & 3.2 & 03 & 3.0 & 4.3 \\
\hline $\mathrm{K}(42) \mathrm{N}$ & 0 & 0 & 0 & 0 & 0 & 0 & 0 & 0 & 0 \\
\hline
\end{tabular}

$\mathrm{C}$ and $\mathrm{N}$ correspond to the control and to $\mathrm{N}_{2}$-flushed cultures, respectively.

${ }^{a}$ culture samples were heat treated for $80^{\circ} \mathrm{C} / 12 \mathrm{~min}$

${ }^{b} N D$, not determined.

Pseudomonas retrieved from raw milk samples, at different stages of the cold chain of milk storage, are quite diverse. Several isolates, including the raw milk isolate $\mathrm{C} 1$, were ascribed to P. tolaasii species based on phenotypic characterisation (MunschAlatossava and Alatossava, 2006). Partial 16S rRNA gene sequencing suggested that $\mathrm{C} 1$ could be a member of Pseudomonas fluorescens species (unpublished data). P. tolaasii is a common mushroom pathogen that produces a white line in agar when streaked in front of a Pseudomonas "reactans" bacterial type (Wong and Preece, 1979); this reaction is due to the interaction of the tolaasin toxin and the white line-inducing principle (WLIP), two cyclic lipodepsipeptides (CLPs) synthesized by these bacteria (Mortishire-Smith et al., 1991; Nutkins et al., 1991). When C1 was tested for tolaasin production in the white line reaction, it did not behave like $P$. tolaasii or P. tolaasii -like strain (Munsch et al., 2002); on the contrary it yielded a typical white line when tested against $P$. tolaasii LMG $2342^{\mathrm{T}}$ (data not shown). These result suggests that $\mathrm{C} 1$ is a CLP producer, has a $P$. "reactans" behavior and produces a WLIP type of lipodepsipeptide. The bacterium Pseudomonas "reactans" was recently re-classified as $P$. fluorescens (Ghequire et al., 2013). The incidence of CLP producers in milk is not well known, but a recent report demonstrated the implication of CLP production in false positive results when screening for antibiotic residues in milk (Reybroek et al., 2014). Considering that tolaasin had an inhibitory effect on Bacillus subtilis and B. megaterium (Rainey et al., 1991) and that C1 is also a CLP producer, both representatives of two different types of CLPs producers, C1 and P. tolaasii LMG $2342^{\mathrm{T}}$, were selected in this study.

As monocultures, the growth of the Gram-(-) representatives $\mathrm{C} 1$ and $\mathrm{LMG} 2342^{\mathrm{T}}$ in BHI broth was inhibited under the $\mathrm{N}_{2}$ flushing at both temperatures $\left(25\right.$ and $15^{\circ} \mathrm{C}$ ) (Figures 1C,D, 3C,D). The temperature had the opposite effect on C1 and LMG $2342^{\mathrm{T}}$ under the $\mathrm{N}_{2}$ treatments. Irrespective of the initial bacterial levels or the growth temperature, under the control conditions, both $\mathrm{C} 1$ and LMG $2342^{\mathrm{T}}$ reached $10^{8} \mathrm{cfu} / \mathrm{ml}$ after 1 day of growth. Under $\mathrm{N}_{2}$ flushing, LMG $2342^{\mathrm{T}}$ reached $10^{8} \mathrm{cfu} / \mathrm{ml}$ after 5 days at $25^{\circ} \mathrm{C}$, but after $2.5 \mathrm{~d}$ at $15^{\circ} \mathrm{C}$. In contrast, $\mathrm{C} 1$ reached $10^{8} \mathrm{cfu} / \mathrm{ml}$ under $\mathrm{N}_{2}$ flushing at $2.5 \mathrm{~d}$ at $25^{\circ} \mathrm{C}$, and at $6 \mathrm{~d}$ at $15^{\circ} \mathrm{C}$. Altogether, the temperature modulated growth inhibition without inducing cell death.

The determinant role of the temperature on cell behaviors under $\mathrm{N}_{2}$ gas flushing was most obvious in the case of the Gram$(+)$ representative $B$. weihenstephanensis $\mathrm{KBAB} 4$ strain grown in monoculture (Figures 1A,B, 3A). The $\mathrm{N}_{2}$ gas flushing of the single culture $(\mathrm{KN})$ was associated with a temperature-dependent effect on KBAB4, where rapid growth (as rapid as the control monoculture $\mathrm{KC}$ ) until the end of exponential phase was followed by an immediate cell death phase at $25^{\circ} \mathrm{C}$ (Figure 1A). Interestingly, the decrease in the number of vegetative cells was not correlated with sporulation; under the $\mathrm{N}_{2}$ treatment sporulation was prohibited, irrespective of whether KBAB4 was grown in mono- or co-cultures (Table 2). The observation that $\mathrm{N}_{2}$ flushing does not promote sporulation was previously reported for psychrotolerant bacteria present in pasteurized milk samples (Munsch-Alatossava et al., 2013).

The examination of the relative numbers of bacterial cells showed that, at $25^{\circ} \mathrm{C}$, in co-culture with either C1 or LMG $2342^{\mathrm{T}}$ (irrespective the initial levels, whether $\mathrm{KBAB} 4$ is the major or minor component in dual cultures) under the $\mathrm{N}_{2}$ treatments, KBAB4 more rapidly dominated at the early growing stages, compared to controls, until $24 \mathrm{~h}$ at which stage both pseudomonads largely outcompeted $\mathrm{KBAB} 4$ (Figure 1).

Conversely, at $15^{\circ} \mathrm{C}$ under $\mathrm{N}_{2}$ flushing, $\mathrm{KBAB} 4(\mathrm{KN})$ followed the control (KC) only in the early phase of the exponential growth; growth was then slowed and finally declined and reached a lower level of viable cells (Figure 3A). Notably, during the collapse period, KBAB4 warded off and exhibited another survival strategy by directing the bacterial genetic machinery to the emergence of SCVs, implying a morphotype of smaller colonies compared to the regular large colony morphotype of KBAB4 (Figure 3A, Table 1). At $15^{\circ} \mathrm{C}$, B. weihenstephanensis KBAB4 responded to the stress, of chemical ( $\mathrm{N}_{2}$ flushing) or biological (bacterial antagonism) nature, by the production of SCVs. In the case of bacterial antagonism, the level of SCVs was dependent on the initial inoculum level of KBAB4, and on the relative abundance of KBAB4 in the co-culture. If $\mathrm{KBAB} 4$ was most disadvantaged, with ratios of $\mathrm{C} 1 / \mathrm{KBAB} 4=78$ and $\mathrm{LMG}$ $2342^{\mathrm{T}} / \mathrm{KBAB} 4=108$, lower numbers of SCVs were observed (Experiment $\mathrm{C}$ in Table 1). SCVs have been described for a wide range of bacteria (Proctor et al., 2006; Schmidt Grant and Hung, 2013). In addition to the atypical colony morphology, many features are different including a slower growth rate. Recently, SCVs were described for B. subtilis strains that had lost their sporulation ability (Maughan and Nicholson, 2011). These changes conferred increased fitness and the alteration of metabolic pathways, including morphological changes such as the arrangements of cells in long filaments; the authors hypothesized the occurrence of different mutational events. Our SEM analysis revealed fairly homogenous KBAB4 bacterial cells (Figure 4), compared to Staphylococcus aureus, where the SCVs were heterogeneous, and presented impaired separation (Kahl et al., 2003). The exposure of $B$. weihenstephanensis $\mathrm{KBAB} 4$ to prolonged $\mathrm{N}_{2}$ flushing revealed cells organized in chains, not separated after cell division (Figures 4B-D). The observations that B. subtilis autolysindeficient mutants show abnormally long chains (Smith et al., 
2000) and that the levels of transcription of genes involved in the biosynthesis of major autolysins were reduced in the postexponential phase in SCVs of B. subtilis (Maughan and Nicholson, 2011) suggest that the $\mathrm{N}_{2}$ flushing affects the expression of autolysins and could lead to impaired cell separation in SCVs of KBAB4 due to mutation(s) in gene(s) associated with autolysin expression. To the best of our knowledge, SCVs have not been previously described for $B$. weihenstephanensis.

The two considered Pseudomonas strains did not produce SCVs at 25 or at $15^{\circ} \mathrm{C}$ in the treatments or controls, although SCVs have been described for P. aeruginosa (Häussler et al., 1999).

Most probably at $15^{\circ} \mathrm{C}, \mathrm{C} 1$ produces a killing factor deleterious to $\mathrm{KBAB} 4$, the disappearance of which in the co-cultures occurred at variable times that was seemingly dependent on the initial ratios (relative numbers of $\mathrm{C} 1$ and $\mathrm{KBAB} 4$ ); the more dominant C1 was, the earlier the killing occurred (Figure 3A, and data not shown). The observation that the cell counts for $\mathrm{KBAB} 4$ in the control co-cultured with $\mathrm{C} 1(\mathrm{~K}(\mathrm{C} 1) \mathrm{C})$ dropped over time at $25^{\circ} \mathrm{C}$ (Figure 1A) suggests that this factor is produced at lower amounts at $25^{\circ} \mathrm{C}$ than at $15^{\circ} \mathrm{C}$. Alternatively or in addition, $\mathrm{KBAB} 4$ grown at $15^{\circ} \mathrm{C}$ could be more sensitive to the action of an antibacterial factor produced by $\mathrm{C} 1$ than when grown at $25^{\circ} \mathrm{C}$ due to temperature-adapted changes in biochemical and biophysical structural components, such as the lipid or fatty acid composition of bacterial cytoplasmic membrane (Chintalapati et al., 2004). Moreover the synthesis of this putative anti-Bacillus factor, produced by $\mathrm{C} 1$, seems to be prevented by $\mathrm{N}_{2}$ flushing at both temperatures, indicating that the $\mathrm{N}_{2}$ treatments can modulate bacterial antagonism (Figures 1A, 3A). Another illustration of the impact on the $\mathrm{N}_{2}$ treatments on bacterial antagonism can be seen in the co-culture of strains $\mathrm{C} 1$ and $\mathrm{KBAB} 4$ at $25^{\circ} \mathrm{C}$, where C1 was more susceptible to the $\mathrm{N}_{2}$ flushing in the presence of $\mathrm{KBAB} 4(\mathrm{C} 1(\mathrm{~K}) \mathrm{N})$ (Figure 1C). Whether CLPs, either tolaasin or WLIP-type, are involved in these antagonistic interactions require further study.

What are the modes of actions of the $\mathrm{N}_{2}$ gas flushing treatment on a bacterial cell? Surely the exclusion of oxygen $\left(\mathrm{O}_{2}\right)$ in the $\mathrm{N}_{2}$-flushed atmosphere is one difference to be considered, but is it the only one, or are there additional direct or indirect factor(s) involved in the $\mathrm{N}_{2}$ flushing action? Pseudomonas species have been categorized as strict aerobes, although they can survive in microaerophilic environments. $P$. aeruginosa can even grow in anaerobic conditions (Filiatrault et al., 2006). Interestingly, the Pseudomonas strains C1 and LMG $2342^{\mathrm{T}}$ tolerated the anaerobic atmosphere under the $\mathrm{N}_{2}$ flushing treatment, although growth rates were reduced both at 25 and $15^{\circ} \mathrm{C}$, presumably due to reduced energy production in the absence of oxygen (Figures 1C,D, 3C,D). B. weihenstephanensis, like B. cereus, is a facultative anaerobe. On the other hand, the growth of B. weihenstephanensis strain KBAB4 was not inhibited during the exponential growth phase, but entered the dead cell phase without undergoing a stationary phase. The dead cell phase of $\mathrm{KBAB} 4$ was most evident and final at $25^{\circ} \mathrm{C}$ (Figures 1A,B). Both SEM and TEM analyses revealed severe cellular damages and numerous protruding bubbles or vesicles that may correspond to expulsed portions of cytoplasm wrapped with cytoplasmic membrane (Figure 2B), indicating the presence of holes in the cell wall and cytoplasmic membrane (Figure 2D). Instead, at $15^{\circ} \mathrm{C}$, the dead phase of KBAB4 was compensated by the recovery of KBAB4 growth and the emergence and further growth of SCVs of KBAB4 (Figure 3A). At $15^{\circ} \mathrm{C}$, strain $\mathrm{KBAB} 4$, with a lower growth rate at the exponential phase, apparently had time to adapt to the environmental stress promoted by the $\mathrm{N}_{2}$ flushing and accordingly expressed several SOS responses, allowing at least a fraction of the cell population to survive through physiological or genetic modes of adaption (Finkel, 2006). Most likely, at $25^{\circ} \mathrm{C}, \mathrm{KBAB} 4$ cells received the stress signals by the $\mathrm{N}_{2}$ flushing treatment to trigger the cells to the programmed cell death (PCD) pathway (Rice and Bayles, 2008; Bayles, 2014). Perhaps the redox-state (such as an intracellular $\mathrm{NADH} / \mathrm{NAD}^{+}$ratio) or an oxygen-independent signal promoted by the $\mathrm{N}_{2}$ flushing treatment could be involved in the control of PCD. Interestingly, a batch culture of KBAB4 in a closed tube (head space volume of air approximately 5\%) did not undergo a dead phase, but exhibited exponential and stationary growth phases similar to the KBAB4 control culture (KC) at $25^{\circ} \mathrm{C}$ (data not shown), suggesting that the lack of $\mathrm{O}_{2}$ is perhaps not the only factor behind the effects of the $\mathrm{N}_{2}$ flushing treatment. Based on our EM analyses, after the $\mathrm{N}_{2}$ flushing treatment at $25^{\circ} \mathrm{C}, \mathrm{KBAB} 4$ cells showed several typical ultrastructural features (Figures 2B,D), which are also associated with the bacterial PCD pathway: membrane depolarisation (by a holin), cell shrinkage and lysis (by an autolysin), and DNA condensation and fragmentation (Rice and Bayles, 2008; Bayles, 2014). Accordingly, we suggest that the bactericidal effects by the $\mathrm{N}_{2}$ flushing treatment could be caused by the activation of the bacterial PCD pathway.

\section{CONCLUSION}

Under the $\mathrm{N}_{2}$ gas flushing treatment, (1) the growth of the Pseudomonas and Bacillus strains was mainly inhibited in exponential and post-exponential phases, respectively; (2) sporulation of the Bacillus strain was prevented; (3) bacterial interactions in co-culture conditions interfered with the susceptibility levels; (4) the growth temperature was a key determinant of behaviors under $\mathrm{N}_{2}$ flushing; (5) most significantly, we found that the combination of the two factors, "growth temperature" and "pure $\mathrm{N}_{2}$ gas flushing," acted in a subtle way on B. weihenstephanensis KBAB4, as the strain formed SCVs at $15^{\circ} \mathrm{C}$, but was lead to cell death at $25^{\circ} \mathrm{C}$.

These observations constitute the first evidence that $\mathrm{N}_{2}$ gas flushing can be deleterious to bacteria.

\section{AUTHOR CONTRIBUTIONS}

Patricia Munsch-Alatossava and Tapani Alatossava conceived and designed the experiments; Patricia Munsch-Alatossava performed the microbiological analyses; Tapani Alatossava performed the preparative work for electron microscopy studies. Both authors analyzed the data and wrote the manuscript.

\section{ACKNOWLEDGMENTS}

This research was supported by a grant from the Matti Sundberg quality research foundation and by a personal grant from the Finnish Cultural Foundation to Tapani Alatossava. We thank Mrs. Mervi Lindman at the electron microscopy unit (Biotechnology Institute, University of Helsinki) for her valuable technical 
support in the preparation and analysis of electron microscopy specimens. We are grateful for the gift of KBAB4 strain to Dr. Vincent Sanchis (INRA Jouy en Josas, France). We thank the reviewers of Frontiers in Microbiology/Section Antimicrobials, Resistance and Chemotherapy for their valuable comments and suggestions.

\section{REFERENCES}

Bayles, K. W. (2014). Bacterial programmed cell death: making sense of a paradox. Nat. Rev. Microbiol. 12, 63-69. doi: 10.1038/nrmicro3136

Chintalapati, S., Kiran, M. D., and Shivaji, S. (2004). Role of membrane lipid fatty acids in cold adaptation. Cell. Mol. Biol. 50, 631-642.

Cousin, M. A. (1982). Presence and activity of psychrotrophic microorganisms in milk and dairy products: a review. J. Food Prot. 45, 172-207.

Dechemi, S., Benjelloun, H., and Lebeault, J. M. (2005). Effect of modified atmospheres on the growth and extracellular enzymes of psychrotrophs in raw milk. Eng. Life Sci. 5, 350-356. doi: 10.1002/elsc.200520082

Filiatrault, M. J., Picardo, K. F., Ngai, H., Passador, L., and Iglewski, B. H. (2006). Identification of Pseudomonas aeruginosa genes involved in virulence and anaerobic growth. Infect. Immun. 74, 4237-4245. doi: 10.1128/IAI.02014-05

Finkel, S. E. (2006). Long-term survival during stationary phase: evolution and the GASP phenotype. Nat. Rev. Microbiol. 4, 113-120. doi: 10.1038/nrmicro1340

Ghequire, M. G., Rokni-Zadeh, H., Zarrineh, P., and De Mot, R. (2013). Draft genome sequence of Pseudomonas fluorescens LMG 5329, a white line-inducing Principle producing bioindicator for the mushroom pathogen Pseudomonas tolaasii. Genome Annouc. 1:e00383. doi: 10.1128/genomeA.00383-13

Godfray, H. C., Beddington, J. R., Crdute, I. R., Haddad, L., Lawrence, D., Muir, J. F., et al. (2010). Food security: the challenge of feeding 9 billion people. Science 327, 812-818. doi: 10.1126/science.1185383

Guinebretière, M. H., Thompson, F. L., Sorokin, A., Normand, P., Dawyndt, P., Ehling-Schultz, M., et al. (2008). Ecological diversification in the Bacillus cereus group. Environ. Microbiol. 10, 851-865. doi: 10.1111/j.1462-2920.2007.01495.x

Gustavsson, J., Cederberg, C., Sonesson, U., Van Otterdijk, R., and Meybeck, A. (2011). "Global food losses and food waste," in Save Food at Interpack Düsseldorf, Germany (Rome: Food and Agricultural Orgaization of the United Nations), 38.

Häussler, S., Tummler, B., Weissbrodt, H., Rohde, M., and Steinmetz, I. (1999). Small colony variants of Pseudomonas aeruginosa in cystic fibrosis. Clin. Infect. Dis. 29, 621-625. doi: 10.1086/598644

Hayes, M. C., and Boor, K. (2001). "Raw milk and fluid products," in Applied Dairy Microbiology, 2nd Edn., eds E. H. Marth and J. L. Steele (New York, NY: Marcel Dekker, Inc.), 59-76.

Huck, J. R., Sonne, M., and Boor, K. J. (2009). Tracking heat-resistant, cold thriving fluid milk spoilage bacteria from farm to packaged product. J. Dairy Sci. 91, 1218-1228. doi: 10.3168/jds.2007-0697

Ivy, R. A., Ranieri, M. L., Martin, N. H., Den Bakker, H. C., Xavier, B. M., Wiedmann, M., et al. (2012). Identification and characterization of psychrotolerant sporeformers associated with fluid milk production and processing. Appl. Environ. Microbiol. 78, 1853-1864. doi: 10.1128/AEM.06536-11

Kahl, B. C., Duebbers, A., Lubritz, G., Haeberle, J., Koch, H. G., Ritzerfeld, B., et al. (2003). Population dynamics of persistent Staphylococcus aureus isolated from the airways of cystic fibrosis patients during a 6-year prospective study. J. Clin. Microbiol. 41, 4424-4427. doi: 10.1128/JCM.41.9.4424-4427.2003

Lapidus, A., Goltsman, E., Auger, S., Gallleron, N., Ségurens, B., Dossat, C., et al. (2008). Extending the Bacillus cereus group genomics to putative foodborne pathogens of different toxicity. Chem. Biol. Interact. 171, 236-249. doi: 10.1016/j.cbi.2007.03.003

Lechner, S., Mayr, R., Francis, K. P., Prüß, B. M., Kaplan, T., Wießner-Gunkel, E., et al. (1998). Bacillus weihenstephanensis sp. nov. is a new psychrotolerant species of the Bacillus cereus group. Int. J. Syst. Bacteriol. 48, 1373-1382.

Markland, S. M., Farkas, D. F., Kniel, K. E., and Hoover, D. E. (2013). Pathogenic psychrotolerant sporeformers: an emerging challenge for low-temperature storage of minimally processed foods. Foodborne Pathog. Dis. 10, 413-419. doi: 10.1089/fpd.2012.1355

Maughan, H., and Nicholson, W. L. (2011). Increased fitness and alteration of metabolic pathways during Bacillus subtilis evolution in the laboratory. Appl. Environ. Microbiol. 77, 4105-4118. doi: 10.1128/AEM.00374-11
Mortishire-Smith, R. J., Drake, A. R., Nutkins, J. C., and Williams, D. H. (1991). Left handed $\alpha$-helix formation by a bacterial peptide. FEBS Lett. 278, 244-246. doi: $10.1016 / 0014-5793(91) 80126-\mathrm{N}$

Munsch, P., Alatossava, T., Marttinen, N., Meyer, J. M., Christen, R., and Gardan, L. (2002). Pseudomonas costantinii sp. nov., another causal agent of brown blotch disease, isolated form cultivated mushroom sporophores in Finland. Int. J. Syst. Evol. Microbiol. 52, 1973-1983. doi: 10.1099/ijs.0.02090-0

Munsch-Alatossava, P., and Alatossava, T. (2006). Phenotypic characterization of raw-milk associated psychrotrophic bacteria. Microbiol. Res. 161, 334-346. doi: 10.1016/j.micres.2005.12.004

Munsch-Alatossava, P., and Alatossava, T. (2007). Antibiotic resistance of rawmilk associated psychrotrophic bacteria. Microbiol. Res. 162, 115-123. doi: 10.1016/j.micres.2006.01.015

Munsch-Alatossava, P., and Alatossava, T. (2011a). "Controlled atmosphere-based improved storage of cold raw milk: potential of $\mathrm{N}_{2}$ gas," in Food Storage, eds G. E. Cohen and C. M. Levin (New York, NY: Nova Science Publishers, Inc.), 99-116.

Munsch-Alatossava, P., Gauchi, J. P., Chamlagain, B., and Alatossava, T. (2012a). Trends of antibiotic resistance in mesophilic and psychrotrophic bacterial populations during cold storage of raw milk. ISRN Microbiol. 2012:918208. doi: $10.5402 / 2012 / 918208$

Munsch-Alatossava, P., Ghafar, A., and Alatossava, T. (2013). Potential of nitrogen gas $\left(\mathrm{N}_{2}\right)$ flushing to extend the shelf life of cold stored pasteurised milk. Int. J. Mol. Sci. 14, 5668-5685. doi: 10.3390/ijms14035668

Munsch-Alatossava, P., Gursoy, O., and Alatossava, T. (2010a). Potential of nitrogen gas $\left(\mathrm{N}_{2}\right)$ to control psychrotrophs and mesophiles in raw milk. Microbiol. Res. 165, 122-132. doi: 10.1016/j.micres.2009.02.002

Munsch-Alatossava, P., Gursoy, O., and Alatossava, T. (2010b). Exclusion of phospholipases (PLs)-producing bacteria in raw milk flushed with nitrogen gas $\left(\mathrm{N}_{2}\right)$. Microbiol. Res. 165, 61-65. doi: 10.1016/j.micres.2008.07.001

Munsch-Alatossava, P., Gursoy, O., and Alatossava, T. (2011b). Improved storage of cold raw milk by continuous flushing of $\mathrm{N}_{2}$ gas separated from compressed air: a pilot scale study. J. Food Process. Technol. 1, 1-4. doi: 10.4172/21577110.1000101

Munsch-Alatossava, P., Ikonen, V., Alatossava, T., and Gauchi, J. P. (2012b). “Trends of antibiotic resistance (AR) in mesophilic and psychrotrophic bacterial populations during cold storage of raw milk, produced by organic and conventional farming systems," in Antibiotic Resistant Bacteria, a Continuous Challenge in the New Millenium, ed M. Pana (Croatia: Intech), 105-124.

Murray, S. K., Kwan, K. K. H., Skura, B. J., and Mc Kellar, R. C. (1983). Effect of nitrogen flushing on the production of proteinase by psychrotrophic bacteria in raw milk. J. Food Sci. 48, 1166-1169.

Nutkins, J. C., Mortishire-Smith, R. J., Packman, L. C., Brodey, C. L., Rainey, P. B., Johnstone, K., et al. (1991). Structure determination of tolaasin, an extracellular lipodepsipdeptide produced by the mushroom pathogen Pseudomonas tolaasii Paine. J. Am. Chem. Soc. 113, 2621-2627.

Proctor, R. A., Von Eiff, C., Kahl, B. C., Becker, K., McNamara, P., Herrmann, M., et al. (2006). Small colony variants: a pathogenic form of bacteria that facilitates persistent and recurrent infections. Nat. Rev. Microbiol. 4, 206-305. doi: $10.1038 /$ nrmicrol384

Rainey, P. B., Brodey, C. L., and Johnstone, K. (1991). Biological properties and spectrum of activity of tolaasin, a lipodepsipetide toxin produced by the mushroom pathogen Pseudomonas tolaasii. Physiol. Mol. Plant Pathol. 39, 57-70. doi: 10.1016/0885-5765(91)90031-C

Rajagopal, M., Werner, B. G., and Hotchkiss, J. H. (2005). Low pressure $\mathrm{CO}_{2}$ storage of raw milk: microbiological effects. J. Dairy Sci. 88, 3130-3138. doi: 10.3168/jds.S0022-0302(05)72995-7

Réjasse, A., Gilois, N., Barbosa, I., Huillet, E., Bevilacqua, C., Tran, S., et al. (2012). Temperature-dependent production of various PlcR-controlled virulence factors in Bacillus weihenstephanensis strain KBAB4. Appl. Environ. Microbiol. 78, 2553-2561. doi: 10.1128/AEM.07446-11

Reybroek, W., De Vleeschouwer, M., Marchand, S., Sinnaeve, D., Heylen, K., De Block, J., et al. (2014). Cyclic lipodepsipeptides produced by Pseudomonas spp. naturally present in raw milk induce inhibitory effects on microbiological inhibitor assays for antibiotic residue screening. PLoS ONE 9:e98266. doi: 10.1371/journal.pone.0098266

Rice, K. C., and Bayles, K. W. (2008). Molecular control of bacterial death and lysis. Microbiol. Mol. Biol. Rev.72, 85-109. doi: 10.1128/MMBR.00 030-07 
Ruas-Madieodo, P., Bada-Gancedo, J. C., Fernandez-Garcia, E., Gonzalez de Lano, D., and De Los Reyes-Gavilan, C. G. (1996). Preservation of the microbiological and biochemical quality of raw milk by carbon dioxide addition: a pilot-scale study. J. Food Prot. 59, 502-508.

Schmidt Grant, S., and Hung, D. T. (2013). Persistent bacterial infections, antibiotic tolerance, and the oxidative stress response. Virulence 4, 273-283. doi: 10.4161/viru. 23987

Smith, T. J., Blackman, S. A., and Foster, S. J. (2000). Autolysins of Bacillus subtilis: multiple enzymes with multiple functions. Microbiology 146, 249-262.

Thorsen, L., Hansen, B. M., Nielsen, K. F., Hendriksen, N. B., Phipps, R. K., and Budde, B. B. (2006). Characterization of emetic Bacillus weihenstephanensis, a new cereulide-producing bacterium. Appl. Environ. Microbiol. 72, 5118-5121. doi: 10.1128/AEM.00170-06

Von Stetten, F., Mayr, R., and Scherer, S. (1999). Climatic influence on mesophilic Bacillus cereus and psychrotolerant Bacillus weihenstephanensis populations in tropical temperate and Alpine soil. Environ. Microbiol. 1, 503-515. doi: 10.1046/j.1462-2920.1999.00070.x

Wiedmann, M., Weilmeier, D., Dineeen, S. S., Ralyea, R., and Boor, K. J. (2000). Molecular and phenotypic characterization of Pseudomonas spp. isolated from milk. Appl. Environ. Microbiol. 66, 2085-2095. doi: 10.1128/AEM.66.5.20852095.2000
Wong, W. C., and Preece, T. F. (1979). Identification of Pseudomonas tolaasii: the white line in agar and mushroom tissue block rapid pitting tests. J. Appl. Bacteriol. 47, 401-407. doi: 10.1111/j.1365-2672.1979.tb01200.x

Conflict of Interest Statement: The authors declare that the research was conducted in the absence of any commercial or financial relationships that could be construed as a potential conflict of interest.

Received: 28 August 2014; accepted: 30 October 2014; published online: 14 November 2014.

Citation: Munsch-Alatossava $P$ and Alatossava $T$ (2014) Nitrogen gas flushing can be bactericidal: the temperature-dependent destiny of Bacillus weihenstephanensis KBAB4 under a pure $N_{2}$ atmosphere. Front. Microbiol. 5:619. doi: 10.3389/fmicb. 2014.00619

This article was submitted to Antimicrobials, Resistance and Chemotherapy, a section of the journal Frontiers in Microbiology.

Copyright (C) 2014 Munsch-Alatossava and Alatossava. This is an open-access article distributed under the terms of the Creative Commons Attribution License (CC BY). The use, distribution or reproduction in other forums is permitted, provided the original author(s) or licensor are credited and that the original publication in this journal is cited, in accordance with accepted academic practice. No use, distribution or reproduction is permitted which does not comply with these terms. 